\title{
Somatostatin Receptor Type 4
}

National Cancer Institute

\section{Source}

National Cancer Institute. Somatostatin Receptor Type 4. NCI Thesaurus. Code C17987.

Somatostatin receptor type 4 (388 aa, $\sim 42 \mathrm{kDa}$ ) is encoded by the human SST R4 gene.

This protein plays a role in the inhibition of proliferation, stimulation of arachidonate release and activation of the mitogen-activated protein (MAP) kinase cascade. 